\title{
Experimental Study of the Feeding Habits of Tilapia zillii (Gervais) in Lake Kinneret
}

\author{
Moshe Gophen \\ Migal Scientific Research Institute, Kiryat Shmone, Israel \\ Email: Gophen@Migal.org.il
}

How to cite this paper: Gophen, M. (2017) Experimental Study of the Feeding Habits of Tilapia zillii (Gervais) in Lake Kinneret. Open Journal of Modern Hydrology, 7, 1-10.

http://dx.doi.org/10.4236/ojmh.2017.71001

Received: January 1, 2017

Accepted: January 22, 2017

Published: January 25, 2017

Copyright $\odot 2017$ by author and Scientific Research Publishing Inc. This work is licensed under the Creative Commons Attribution International License (CC BY 4.0). http://creativecommons.org/licenses/by/4.0/

\begin{abstract}
The feeding habits of the cichlid Tilapia zillii (Gervais) in Lake Kinneret (Israel) were experimentally studied in indoor glass containers $(2.5 \mathrm{hrs})$ and two trials in outdoor $5 \mathrm{~m}^{3}$ tanks (20 - 25 days). The trait of food particle collection by adult fishes was measured. A survey was carried out in the littoral ( $0-1.0 \mathrm{~m}$ deep) zone and fingerlings were sampled by electro-chocker. The gut content of the fingerlings was analyzed. The feeding habits of T. zillii were indicated as planktivorous filtration with more enhancements of small zooplankters (Nauplius, Brachionid rotifers) and fewer of Cladocerans suppressions.
\end{abstract}

Keywords

Tilapia zillii, Kinneret, Feeding, Ecological Adaptation

\section{Introduction}

Fish feeding habits and food particle selectivity are known to be correlated with their actual habitat or their geo-ecological origin. Nevertheless, natural ichthyofaunal diversity initiates food resources partitioning, and the ecological structure of Lake Victoria is a well known versatile system. The original fish community of Lake Kinneret includes 19 species from three primary and four secondary freshwater originated families [1]. Three exotic species which are annually introduced comprise a significant part of the Kinneret Ichthyofauna. From the Zoogeographical viewpoint, 6 species are Paleoarctician, 9 species are Ethiopian, and 4 species are Endemic [1]. It was suggested that Tilapias were originated in marine ecosystems and migrated into freshwater habitats [2] [3] [4] [5] [6]. Consequently, euryhalinity in many of the Tilapia species is known worldwide [7]. Several Tilapia species ( T. guineensis, S. melanotheron, O. mossambicus, $O$. hornorum and $O$. placidus) are highly tolerant to salinity levels of up to $30 \mathrm{ppt}$ populate and reproduce in estuaries and lagoons along Western and Eastern African coasts [7]. Nevertheless, the natural reproductions of only two species (O. mosammbicus, T. zillii) 
were reported in seawaters [8] [9] [10] [11]. In the saline (29.4 ppt) Lake Quarun, Suez Bay (43 ppt), and Bardawil Lagoon (41 - 45 ppt), Egypt, adult (not fingerlings) T. zillii is the only common Tilapia that exists [8] [11] [12]. Studies on food composition of $T$. zillii in nature and cultured were previously carried out [5] [13] [14]. Nevertheless, the habit of food item collection was not yet widely reported. The aim of the present study is to clarify food item selectivity as well as characterization of natural preference of salinity. T. zillii is able to change its appearance by melanistic-marking pattern [15]. It was concluded that those melanistic variabilities, as also documented in other cichlids, were resulted by stressors such as attack-escape, darkening, territorial and spawning but not feeding behaviour. Therefore, the idea of the existence of more than one species of $T$. zillii in Lake Kinneret cannot be confirmed presently and DNA structure is required. With regard to food availability, the resource partitioning is critical [16]. If the food resource usage is different between coexisting planktivore Tilapia species in Lake Kinneret, particle selection in the multi-species experimental system might give the answer. The practical expected implicated objectives from the study are focused on the understanding of the process of adaptation of Tilapia zillii within the Kinneret ecosystem as background of water quality and fishery managements design.

\section{Material and Methods}

\subsection{Glass Indoor Containers Experiment}

The Glass container experiments design was as follows. The experiment was carried out in five $120 \mathrm{~L}$ glass indoor containers (Aquarium), each containing $112 \mathrm{~L}$ of filtered (63 $\mu$ mesh size net) lake water under ambient indoor conditions: diffused light; $23^{\circ} \mathrm{C}$ $26^{\circ} \mathrm{C}$ stable room temperature. T. zillii specimen were placed (Table 1 ): 1 fish in each of containers 1, 2 and 2 fishes in containers 4 and 5, and 1 fishless container.

Fishes were introduced into the containers with filtered lake water two days before experiments started for acclimatization. Fresh plankton was collected in the lake containing $63 \mu$ mesh size plankton net and re-suspended in lake water. The same aliquot of fresh plankton suspension was given to the fishless and each other container. Samples were collected in the containers immediately after the insert of the plankton suspension (Initial time) and 2.5 hours later. The containers were not aerated and re-suspension of dead organisms was prevented. Experimental sampling was done with a plastic cylinder open on both sides and a rubber stopper. The stopper was gently placed on the bottom and the plastic pipe was vertically lowered onto the stopper closing

Table 1. Experimental design: number of specimens and their body parameters: Total Length $(\mathrm{cm})$, Total Weight $(\mathrm{g})$.

\begin{tabular}{ccc}
\hline Total Length $(\mathrm{cm})$ & Weight $(\mathrm{g})$ & Container No. \\
\hline 13 & 50.5 & 1 \\
19 & 126.4 & 3 \\
16.3 & 80.0 & 4 \\
21 & 81 & \\
17 & 153 & 5 \\
19.3 & 147.8 & 5 \\
16.6 & 88.5 & \\
\hline
\end{tabular}


sampled water within the pipe. Then the cylinder was picked with its bottom blocked by the stopper. The volume of the sample was measured before filtering through $63 \mu$ mesh size net. All collected organisms were flushed from the net collector into a small beaker and preserved by $0.5 \mathrm{cc}$ ( $1 / 10$ of the sample volume) of $10 \%$ formalin. Counting was carried out under Wild Binocular through wheel-counting-chamber. Each sampling included 3 repetitions and result was averaged. The plankton was divided into the following four categories: 1) Copepod nauplii, 2) 1 - 4 copepodite stages, 3) $5^{\text {th }}$ copepodite stage and adult copepods, and 4) all cladocerans (Bosmina spp., Diaphanosoma sp., Ceriodaphnia $s p p$ ). All concentrations were expressed as number per litre. Number of consumed (eliminated) organisms was considered as those resulting from the subtraction of $2.5 \mathrm{hrs}$ concentration from initial concentration after the elimination of mortality as resulting from concentration measured in fishless containers. In containers with two fishes, results were calculated as number of consumed organisms per individual fish.

\section{2. $5 \mathrm{~m}^{3}$ Outdoor Experiments}

The study of the feeding habits of the fish include 4 steps: 1) gut content analysis of lake sampled fishes; 2) Glass containers with individual body size measured specimen (1 - 2 per container) for the investigation of single fish fed by known food items for the study of Index Of Electivity; 3) The $5 \mathrm{~m}^{3}$ Outdoor tanks contained the background of natural un-treated food resources removed from the lake and the addition of zooplankton, fish and both combination for the preferential habits of the fish. The gut content study was presented earlier and the two steps forward are given here.

Two trials (20, 25 days each) were run in $5 \mathrm{~m}^{3}$ outdoor tanks filled with lake water to examine the impacts of fish and zooplankton on lake plankton. Tanks were filled at the beginning of each experiment with water pumped from approximately $30 \mathrm{~m}$ offshore at a depth of $1.5 \mathrm{~m}$. T. zillii were placed into 4 of 8 tanks: 2-with supplemented fresh zooplankton collected in the lake by $300 \mu$ mesh size net and equal portions of the composite added to tanks; 2 -control, and 2-with both fish and zooplankton. Treatment combinations were in a $2 \times 2$ factorial design. Several parameters were measured weekly. Results were analyzed by ANOVA for the significance of main effect and interactions by Duncan grouping for fish and zooplankton treatment. Fish ( T. zillii) were collected from the lake and acclimated in the tanks filled with lake water several days prior to experimental periods. During experimental time, tanks were mixed for 2 hours a day by an air-lift mixer system. Mixers moved a water volume equivalent to tank volume in about 1 hour destratifying and aerating the tanks. Tanks were weekly sampled for zooplankton counts and Chlorophyll analysis (Wetzel and Likens 2000); by mixing 5 replicate samples collected with $2.5 \mathrm{~m}$-long $1.5 \mathrm{~cm}$-diameter plastic pipe lowered to few $\mathrm{cm}$ above tank bottom. Chlorophyll analysis was carried out on pipe samples [17] and zooplankton counts were done using a dissecting microscope on animals collected in a one-net (63 m mesh-size) haul from bottom to tank surface.

\section{Results}

\subsection{Glass Indoor Container Experiment}

Results in terms of consumed organisms per fish per $2.5 \mathrm{hrs}$ in 5 containers are given in 
Table 2 and Table 3.

The highest number of consumed organisms is due to the smallest-sized Nauplius and the highest consumed biomass to the largest body-sized caladocerans. Nevertheless, the highest index of electivity is that of Nauplius and the lowest that of Cladocerans. The efficiency of small organisms (Nauplius and small copepodites) ingestion $(\mathrm{E}=0.73$ and 0.22 , respectively) is much higher than those of large body organisms ( 4 - 5 copepodites, adult cyclopoids and cladocerans) $(\mathrm{E}=-0.04$ and -0.11 , respectively). T. zillii is conclusively considered as filter feeding fish and partly visual attacker.

$$
E=r_{1}-p_{1} / r_{1}+p_{1}
$$

where:

$$
\begin{aligned}
& r_{1}=\% \text { of Consumed Food Component; } \\
& p_{1}=\% \text { of Food Component in the Control at Initial Time. }
\end{aligned}
$$

\section{2. $5 \mathrm{~m}^{3}$ Outdoor Experiments}

Analyses of three effects were done: Zooplankton Effect, Fish Effect and Main Effect based on data sums across sampling dates in the tanks: 2-control, no fish no

Table 2. Glass Container Experiments: Number of organisms (Nauplius; 1 - 3 stages Copepodite; $5^{\text {th }}$ copepodite and adult copepods; Cladocerans) as concentrations (No./L) decline considered as Glass Container experiments consumed per individual fish.

\begin{tabular}{ccccc}
\hline $\begin{array}{c}\text { Container } \\
\text { No. }\end{array}$ & Nauplius & $\begin{array}{c}\text { 1 - 3 Stage } \\
\text { Copepodite }\end{array}$ & $\begin{array}{c}\text { Copepodi } \\
\text { 5+ Adult copepods }\end{array}$ & Cladocerans \\
\hline 1 & 83 & 8 & 14 & 9 \\
2 & 121 & 57 & 2 & 24 \\
3 & 105 & 18 & 6 & 9 \\
4 & 78 & 9 & 3 & 3 \\
5 & 39 & 6 & 1 & 9 \\
Averaged & $85(31)$ & $20(21)$ & $5(5)$ & $11(8)$ \\
$\begin{array}{c}\text { Consumed } \\
\text { (SD): No./L }\end{array}$ & & & & \\
\hline
\end{tabular}

Table 3. Consumed Biomass ( $\mu \mathrm{g} / \mathrm{L})$ during 2.5 hrs, \% are shown. Biomass computation is based on the mean individual wet weight ( $\mu \mathrm{g} /$ Individual) in each group [18]: Nauplius-0.9 $\mu \mathrm{g} / \mathrm{L} ; 1$ - 3 copepodite stages- $4.23 \mu \mathrm{g} / \mathrm{L} ; 4$ - 5 copepodite stages \& adults- $12.7 \mu \mathrm{g} / \mathrm{L}$; Cladocera-34.8 $\mu \mathrm{g} / \mathrm{L}$. Biomass $(\mu \mathrm{g} / \mathrm{L})$ and numerical compositions (No./L) of zooplankton in control container at the initial time are given. The outcomes are Indicies of Electivity [19] (see Equation (1)) as shown in Figure 1 .

\begin{tabular}{ccccc}
\hline Organism & $\begin{array}{c}\text { Biomass } \\
\text { Consumed } \\
(\mu \mathrm{g} / \mathrm{L})\end{array}$ & $\begin{array}{c}\text { Biomass } \\
\text { Consumed } \\
(\%)\end{array}$ & $\begin{array}{c}\text { Control Initial } \\
(\mathrm{No} / \mathrm{L})\end{array}$ & $\begin{array}{c}\text { Control Initial } \\
(\mu \mathrm{g} / \mathrm{L})(\%)\end{array}$ \\
\hline $\begin{array}{c}\text { Nauplius } \\
1-3 \text { Copepodite }\end{array}$ & 85 & 13 & 44 & $39.6(2 \%)$ \\
$4-5$ Copepodite \& & 14 & 49 & $207.3(9 \%)$ \\
Adults & 64 & 11 & 20 & $254(11 \%)$ \\
Cladocerans & 383 & 62 & 50 & $1740(78 \%)$ \\
\hline
\end{tabular}




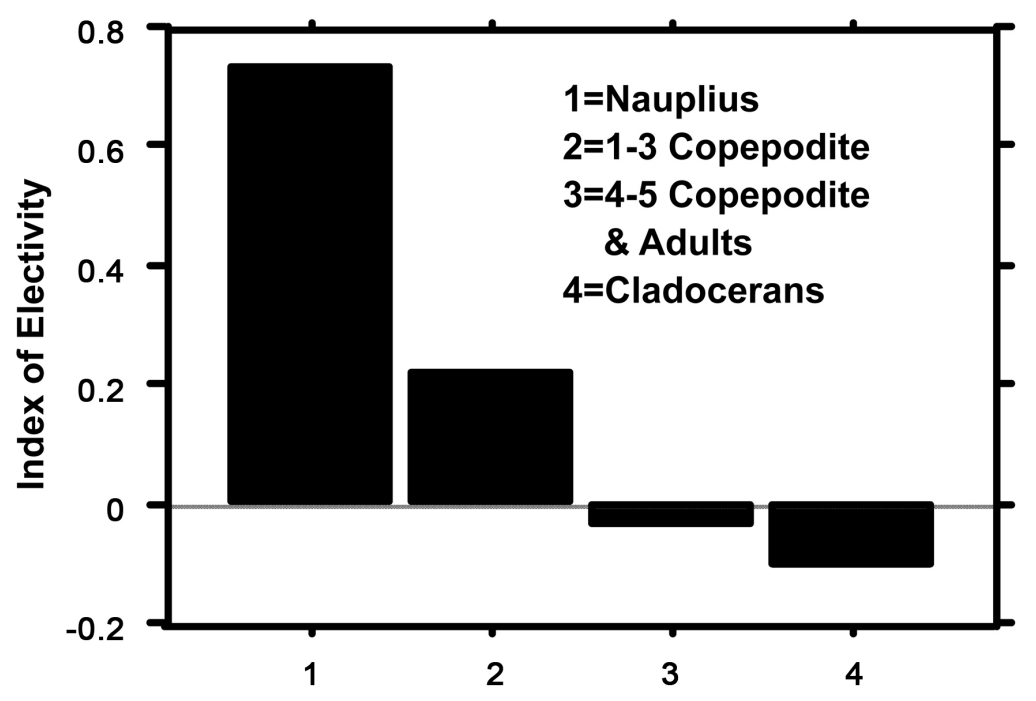

Figure 1. (Glass Containers Experiment): Index of Electivity [19] (See Equation (1)): $n_{1}=$ consumed food component biomass $(\mu \mathrm{g} / \mathrm{L})$ and their compositional $\%$ averaged for 5 containers; $p_{1}=$ Biomas $(\mu \mathrm{g} / \mathrm{L})$ composition $(\%)$ in the control container at initial time.

Zooplankton addition; 2-Zooplnkton addition, 2-Fishe addition and 2-addition of Zooplankton and Fish. There was a significant main effect of Fish on Chlorophyll and on Cladoicera in the $1^{\text {st }}$ experiment: $p=0.048$ and 0.012 , respectively; Zooplankton addition significantly affected copepod concentration in the $1^{\text {st }}$ experiment and Cladocera concentration in the $2^{\text {nd }}$ experiment. No significant interaction between zooplankton and fish additions was indicated. In the tanks with fish, chlorophyll increased in the two experiments accompanied by a decline of Cladocera. Evaluation of Fish and Zopoplankton main effects were achieved by comparing the mean values for treatments containing fish and zooplankton with those from which it is absent (Control). Probability values are given in Table 4 (Figure $2 \&$ Figure 3 ). Experiments were $2 \times 2$ factorial design (presence or absence of Zooplankton addition $\mathrm{X}$ presence or absence of Fish for the analysis of main and interaction effects. Treatment combination included also nofish-no zooplankton replicate. The community structure information were analyzed using a multivariate profile analysis of repeated measures [20] [21] [22] summary of data across sampling dates into univariate test to detect treatment effects [20].

\subsection{Food Composition}

\subsubsection{Fingerlings}

As part of the ecological study of the Kinneret littoral-shallow waters, fingerlings are captured by Electro-Shocker. The sampling program included shallow water $(0-1.0 \mathrm{~m}$ depth) stations along total shoreline length. Among other species, fingerlings of T. zillii were fished mostly in the West-Southern and Northern regions. The bottom in those sites was varieties of muddy-sandy-pebble stony compositions. The body size (TL, cm) range of the captured fingerlings was $4-8 \mathrm{~cm}$. Samplings were carried out monthly and 5 specimens were sub-sampled. The sub-sampled fingerlings were measured and placed immediately into $10 \%$ formalin solution and were later on dissected for the analysis of the gut contents under dissecting and inverted microscopes. 
Table 4. Probability values for Zooplankton and Fish main effects and Interactions. Statistical significance (S) was inferred at the $p<0.1$ level [20] [21] [22] (Figure $2 \&$ Figure 3).

\begin{tabular}{|c|c|c|c|}
\hline Parameter & $\begin{array}{c}\text { Zooplankton } \\
\text { Main Effect }\end{array}$ & Fish Main Effect & Interaction \\
\hline \multicolumn{4}{|l|}{$1^{\text {st }}$ Experiment } \\
\hline Chlorophyll & 0.364 & 0.406 & $0.048 \mathrm{~S}$ \\
\hline Copepods & $0.021 \mathrm{~S}$ & 0.462 & 0.156 \\
\hline Nauplius & 0.751 & 0.590 & 0.305 \\
\hline Copepodite & $0.092 \mathrm{~S}$ & 0.961 & 0.294 \\
\hline Cladocera & 0.240 & 0.619 & $0.012 \mathrm{~S}$ \\
\hline Rotifera & 0.310 & 0.737 & 0.914 \\
\hline Turbidity & 0.874 & 0.895 & 0.461 \\
\hline \multicolumn{4}{|l|}{$2^{\text {nd }}$ Experiment } \\
\hline Turbidity & 0.463 & 0.303 & 1.000 \\
\hline Chlorophyll & 0.808 & 0.704 & $0.048 \mathrm{~S}$ \\
\hline Nauplius & 0.669 & 0.622 & 0.114 \\
\hline Copepodite & 0.532 & 0.820 & 0.760 \\
\hline Cladocera & $0.050 \mathrm{~S}$ & 0.790 & 0.725 \\
\hline Rotifera & 0.976 & 0.740 & $0.092 \mathrm{~S}$ \\
\hline
\end{tabular}
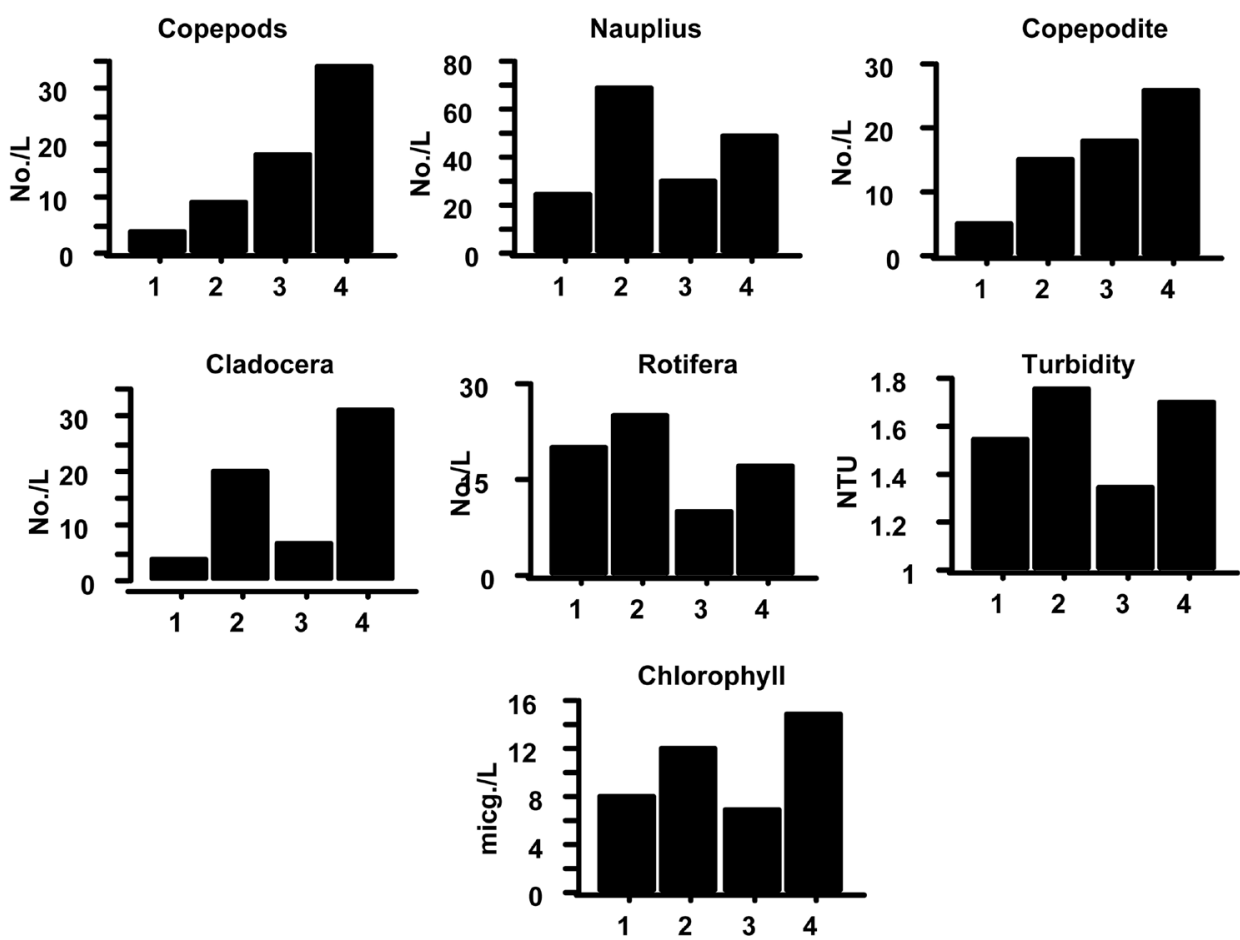

Figure 2. (First Tanks experiment). Mean values in Control (1), Fish (2), Zooplankton (3) and Zooplankton + Fish Treatment (4) combinations: Chlorophyll $(\mu \mathrm{g} / \mathrm{L})$, Turbidity (NTU) and densities (No./L) of Nauplius, Copepodite (1 - 3 stages) Adults and 4 - 5 copepodite stages ("Copepoda"), Cladocera and Rotifera. 

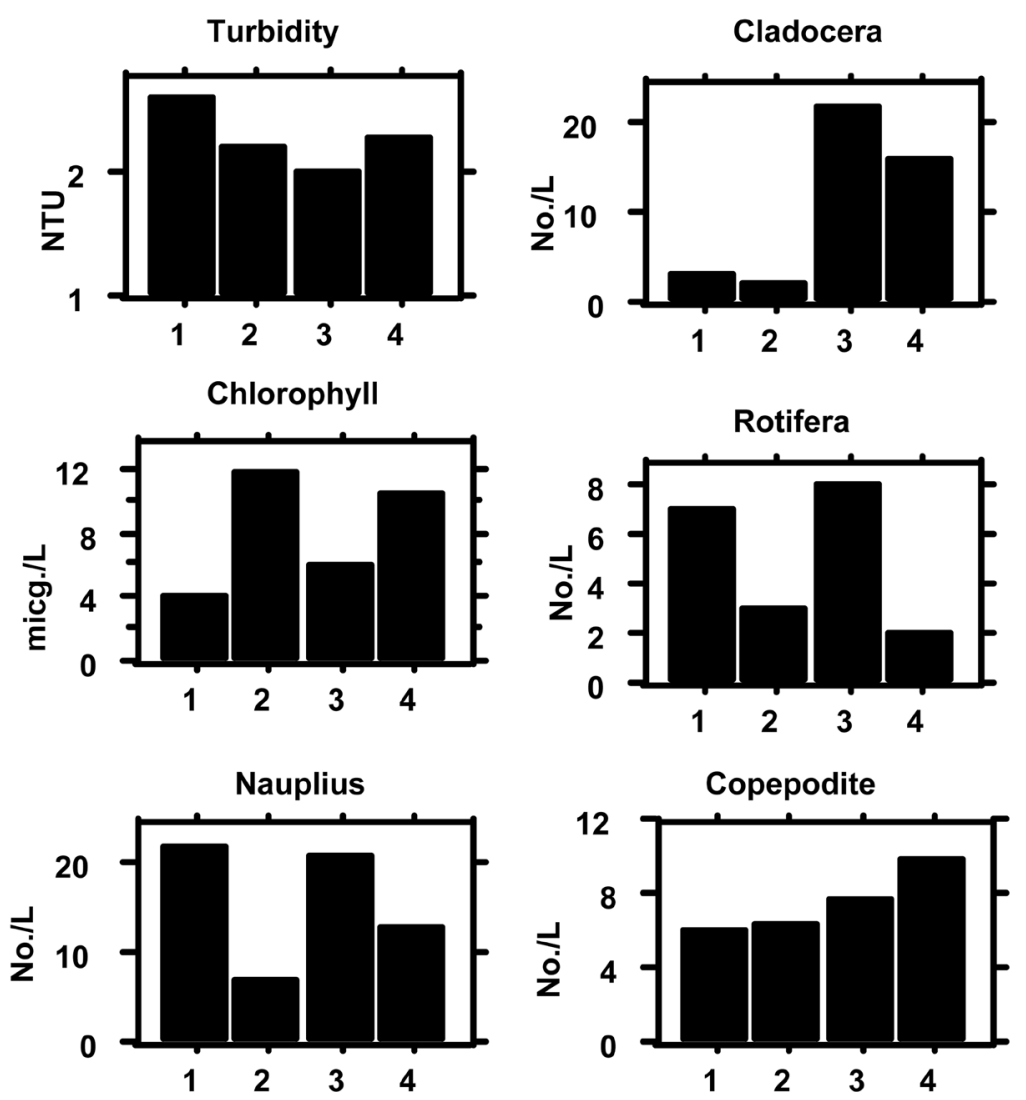

Figure 3. (Second Tanks experiment). Mean values in Control (1), Fish (2), Zooplankton (3), and Zooplankton + Fish Treatment (4) combinations: Chlorophyll ( $\mu \mathrm{g} / \mathrm{L})$, Turbidity (NTU), and densities (No./L) of Nauplius, Copepodite (1 - 3 stages), Cladocera and Rotifera.

The most common items in the fingerling intestines were Intact and broken Foraminifer shells, Intact and broken shells of the Gastropod Melanoides sp., sand grains, Frustulae of Centrales and Pennales Diatoms, short (broken) filaments of Melosira sp. body parts, (fragments) of Chironomid larvae, small size chlorophytes (Scenedesmus spp., Cosmarium spp., Pediastrum spp.), high plant debris, small rotifers (Brachionids), and Spiculae of Porifera. This type of food composition is typical to bottom burrowers or dweller freshwater fishes.

\subsubsection{Adults Food}

The adults are omnivores which collect food by different techniques [14]: active visual attack, lip palpation of stable items, stone scratching, mud burrowing/dwelling, plankton filtering, and also active prey (young fingerling) chasing. The principal component of the adults throughout most of the seasons is chironomid larvae and zooplankton; supplemental sources are cyanophyte and dinoflagellate algae, periphyton and drifted insects, Nematodes, Ostracodes, Porifera (spiculae).

\section{Discussion}

The very high range of water salinity ( $0.4-43$ ppt Chloride concentration) populated by $T$. zillii is indicates the high saline tolerance of $T$. zillii. Nevertheless, the optimal 
condition for a natural complete lifecycle is probably not marine. It is suggested that the origin might be marine conditions but after long-term adaptation the fish's natural habitat was established in freshwater. The high saline tolerance of $T$. zillii is probably an evolutionary relict of marine origin. The food composition of T. zillii in marine condition is not known but the documented absence of fingerlings and reproductive behavior confirmed freshwater conditions as preferential habitats. The intensive consumption of the lake and running water food sources indicate an adaptive evolutionary process in freshwater. Moreover, the aggressive reproductive behavior, the diversity of the granulometric composition of the nest structure and substrate composition [4] [5], as well as the versatility of body colored patterns [15], indicate also the high level of evolutionary adaptation of a freshwater fish that originated in a brackish water environment. It can be comparatively considered with the distribution of Mugilid fishes. The mugilids live in marine habitats and reproduce in freshwater river inlets where salinity is lower. $\mathrm{Mu}$ gilids survive and grow significantly in Lake Kinneret and are cultured in freshwater aquaculture but do not reproduce. T. zillii and several mugilid species originated in marine habitats but the former completed evolution and moved into freshwater (Anadromus) when the latter only partly adapted to terrestrial lakes and rivers and live in marine waters.

To indicate the level of freshwater adaptation performed by $T$. zillii, four major features are considered: reproduction, feeding and food relation, tolerance of salinity changes [23] and temperature suitability. The factor of temperature is significant since the fish belong to the Ethiopian region characterized by high temperatures. This factor was discussed in [5] where a case of mass mortality of the fish was documented during exceptional temperature decline in Lake Kinneret followed by a parasite infection [5]. The selected suitability of bottom substrate for nest construction was documented [4]. The wide level of salinity where T. zillii was recorded is given in the introduction.

The parameters of feeding and food relations were studied in this paper. It is suggested that adult T. zillii preferentially select small zooplankters. Nevertheless, this preferential selection is a result, not of visual collection of food particle, but of swimming and the escapeability trait of the species preyed on. Visible adult cyclopoid copepods and 1 - 4 copepodite stages are better escapers then the non-visible nauplius, young copepodites and small rotifers (Brachionids). Therefore, these small and poorer escaper organisms are consumed through pumping activity of the fish at a higher rate than adults and older copepodites. The ingestion of small organisms (Nauplius, young copepodites and Brachiond rotifers) is maintained by filtration of pumped water, and large animals (matured copepodite, adult cyclopoid copepods and cladocerans) are captured by a visual attack. Significant probabilities were indicated for interaction effect on Chlorophyll enhancement in the two tank experiments, as well as on Cladocera in the first experiment and on Rotifera in the second experiment (Figure 2 \& Figure 3). Such chlorophyll enhancement probably resulted from predation pressure of fish produced on small zooplankters (Nauplius and Brachionid rotifers). Nauplius decline (Figure 2) is related to fish predation. Interaction effect on Cladocera in the first experiment was probably due to additional zooplankton main effect as fish predation was confirmed by the Index of Electivity (E) (Figure 1). Moreover, it is possible that the 
poor predation of cladocerans by fish was confounded by zooplankton addition.

The strong adaptation of reproductive behavior, nest construction and taking care of the fertilized eggs and newborn larvae by both male and female are also correlated between the available food sources for the YOY in the shallows of the Kinneret littoral zone. It is suggested that the information collected in the present study and those performed earlier enable lake managers to establish evidence for rules of fishery management legislations aimed at water quality protection and fishery regulations.

\section{Summary}

The ecological success of the evolutionary adaptation process of $T$. zillii in Lake Kinneret is expressed by the fish's passivity to suitable food required for the adult and the young life cycle stages, a suitable substrate for nest construction and suitable temperatures. This paper documented the food resources suitability for the optimal existence of T. zillii in Lake Kinneret. Experiments carried out in glass containers confirmed T. zillii s feeding habits of planktivor filtration and the $5 \mathrm{~m}^{3}$ tank trials indicated more enhancements of small zooplankters and less cladocerans suppression.

\section{Acknowledgements}

I wish to express my thanks to Dr. O. Sonin, Z. Snovski and J. Shapiro for supporting of facilities and assistance of fingerling sampling in the littoral zone (Project No. 5960527-12). Design, operation and statistical analysis of the Outdoor tank experiments (NSF Research Grant No. BSR-8416519) were carried out by the late Dr. G.L. Vinyard, an outstanding scientist, friend and collaborator.

\section{References}

[1] Ben-Tuvia, A. (1978) Chapter Fishes. In: Serruya, C., Ed., Lake Kinneret Monographiae Biologicae, Vol. 32, Dr. W. Junk Publishers, The Hague-Boston-London, 407-431.

[2] Meyers, G.S. (1938) Fresh Water Fishes and West Indian Zoogeography. Publication No. $3465,399$.

[3] El-Bolock, A.R. and Koura, R. (1961) The Age and Growth of Tilapia galilaea Art., T. Nilotica L. and T. zillii Gerv., from Beteha Area (Syrian Region), Notes and Memoires No. 59, United Arab Republic (Southern Region), Ministry of Agriculture. Hydrobiological Department, Institute of Freshwater Biology, Gizira-Cairo, 1-27.

[4] Bruton, M.N. and Gophen, M. (1992) The Effect of Environmental Factors on the Nesting and Courtship Behaviour of Tilapia zillii in Lake Kinneret (Israel). Hydrobiologia, 239, 171178. https://doi.org/10.1007/BF00007674

[5] Gophen, M. (2016) Study on the Biology of Tilapia zillii (Gervais, 1848) in Lake Kinneret, (Israel). Open Journal of Ecology, 6, 167-175. https://doi.org/10.4236/oje.2016.64017

[6] Chervinski, J. (1987) Tilapia zillii (Gervais) in the Mediterranean. Bamidgeh, 39, 133-134.

[7] Philippart, J.C. and Ruwet, J.C. (1982) Chapter: Ecology and Distribution of Tilapias. In: Pullin and Lowe-McConel, Eds., The Biology and Culture of Tilapias, ICLARM Conference Proceedings, Int. Center for Living Aquatic Resources Management, Manila, Philippines, 15-59.

[8] Chervinski, J. (1972) Occurrence of Tilapia zillii (Gervais) (Pusces, Cichlidae) in the Bardawill Lagoon Northern Sinai. Bamidgeh, 24, 49-50.

[9] Chervinski, J. and Zorn, M. (1974) Note on the Growth of Tilapia aurea (Steindachner) and 
Tilapia zillii (Gervais) in Sea-Water Ponds. Aquaculture, 4, 249-255. https://doi.org/10.1016/0044-8486(74)90037-4

[10] Popper, D. and Lichatowitch, T. (1975) Preliminary Success in Predator Control of Tilapia mossambica. Aquaculture, 5, 213-214. https://doi.org/10.1016/0044-8486(75)90101-5

[11] Bayumi, A.R. (1969) Notes on the Occurrence of Tilapia zillii in Suez Bay. Marine Biology, 44, 255-256. https://doi.org/10.1007/BF00393903

[12] El-Zarka, S.D. (1961) Tilapia Fisheries Investigation in Egyptian Lakes: II: A Biological Studies of Fisheries of Tilapia zillii Gervcais in Lake Quarun, Egypt. U.A.R. Notes Mem, Hydrobiol, Fish, Dir, Cairo, Vol. 66, 1-14.

[13] Legner, E.F. and Medved, R.A. (1973) Predation of Mosquitos and Chironomid Midges in Ponds by Tilapia zillii (Grvais) and T. Mossambica (Peters) (Telreosteii: Cichlidae). 41 st Annual Conference California Mosquito Control Association, 28-31 January 1973, 119-121.

[14] Spataru, P. (1978) Food and Feeding Habits of Tilapi zillii (Gervais) (Cichlidae) in Lake Kinneret. Aquaculture, 14, 327-338. https://doi.org/10.1016/0044-8486(78)90015-7

[15] Hulscher-Emeis, T.M. (1991) A Causal Ethological Analysis of the Display of Variable Color Patterns in the Fish Tilapi zillii (Cichlidae). PhD Thesis, Rijksuniversiteit Te Groningen, Groningen, $131 \mathrm{p}$.

[16] Gerking, S.D. (1994) Food Partitioning and Diet Switches. In: Gerking, S.D., Ed., Feeding Ecology of Fish, Academic Press, Cambridge, 299-315.

[17] Wetzel, R.G. and Likens, G.E. (2000) Composition and Biomass of Phytoplankton. In: Wetzel, R.G. and Likens, G.E., Eds., Limnological Analyses, 3rd Edition, Springer, New York, 147-154.

[18] Gophen, M. and Azoulay, B. (2002) The Trophic Status of Zooplankton Communities in Lake Kinneret (Israel). Verhandlungen des Internationalen Verein Limnologie, 28, 836-839.

[19] Ivlev, V.S. (1961) Experimental Ecology of Feeding of Fishes. Yale University Press, New Haven.

[20] Wilkinson, L. (1984) Systat Statistical Package. Systat Inc., Evanston.

[21] Winer, B. (1971) Statistical Principles in Experimental Design. 2nd Edition, McGraw-Hill, New York.

[22] Vinyard, G.L., Drenner, R.W., Gophen, M., Pollingher, U., Winkelman, D.L. and Hambright, K.D. (1988) An Experimental Study of the Plankton Community Impacts of Two Omnivorous Filter-Feeding Cichlids, Tilapia galilaea and Tilapia aurea. Canadian Journal of Fisheries and Aquatic Sciences, 45, 685-690. https://doi.org/10.1139/f88-082

[23] Gophen, M. (2016) A Review on Modeling of Kinneret Salinity with Practical Recommendations. Open Journal of Modern Hydrology, 6, 129-139.

https://doi.org/10.4236/ojmh.2016.63011 
Submit or recommend next manuscript to SCIRP and we will provide best service for you:

Accepting pre-submission inquiries through Email, Facebook, LinkedIn, Twitter, etc. A wide selection of journals (inclusive of 9 subjects, more than 200 journals) Providing 24-hour high-quality service

User-friendly online submission system

Fair and swift peer-review system

Efficient typesetting and proofreading procedure

Display of the result of downloads and visits, as well as the number of cited articles Maximum dissemination of your research work

Submit your manuscript at: http://papersubmission.scirp.org/

Or contact ojmh@scirp.org 